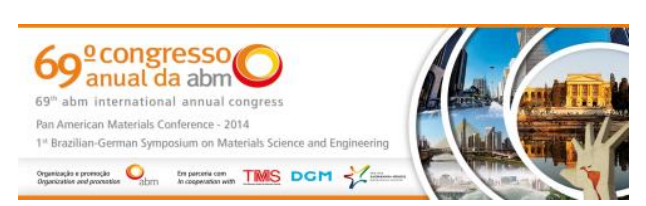

Theme: Physical metallurgy and material behavior at high temperatures

\title{
THE ISO 5832-9 STEEL HOT FLOW CURVES, AN ANALYTICAL STUDY*
}

\author{
Samuel Filgueiras Rodrigues ${ }^{1}$ \\ Gedeon Silva Reis ${ }^{2}$ \\ Regina Célia Sousa ${ }^{3}$ \\ Eden Santos Silva ${ }^{4}$ \\ Mauro Araújo medeiros ${ }^{5}$
}

\begin{abstract}
An austenitic stainless steel ISO 5832-9 was deformed in a torsion test machine over the temperature range of $1,000^{\circ} \mathrm{C}-1,200^{\circ} \mathrm{C}$ and strain rates of $0.05,0.1,1.0$ and $5.0 \mathrm{~s}^{-1}$. The Steel plastic behavior was studied by analyzing the flow curves shapes and using the constitutive equations under the conditions of thermomechanical treatment. The curves initially presented an increase in stress characterized by hardening work, followed by a drop in stress to an intermediate level that reached or not, for certain conditions, the steady state softening. The plastic flow curves of ISO 5832-9 steel displayed in three different ways: (i) Curves with continuous softening presenting plastic instability for low temperatures and high strain rates; (ii) curves type flat, here after the peak there is little variation of stress with strain presenting softening mechanism by higher contribution of dynamic recovery at low temperatures and low and intermediate strain rates; (iii) curves with softening after the critical deformation favored by high temperatures and low strain rates. These behaviors indicate the influence of the stacking fault energy (SFE) and precipitated particles on the softening kinetics of this steel.
\end{abstract}

Keywords: Austenitic stainless steel; Hot flow curves; Dynamic recovery; Dynamic recrystallization.

1 Física, Mestre, Professor, Departamento de Mecânica e Materiais, Instituto Federal de Educação, Ciência e Tecnologia do Maranhão (IFMA), São Luís, MA, Brasil.

2 Engenharia Mecânica, Doutor, Professor, Departamento de Engenharia Mecânica e Materiais, Instituto Federal de Educação, Ciência e Tecnologia do Maranhão (IFMA), São Luís, MA, Brasil.

3 Física, Doutora, Professora, Departamento de Física, Universidade Federal do Maranhão (UFMA), São Luís, MA, Brasil.

4 Física, Doutor, Professor, Departamento de Física, Instituto Federal de Educação, Ciência e Tecnologia do Maranhão (IFMA), São Luís, MA, Brasil.

5 Engenharia Mecânica, Doutor, Professor, Departamento de Engenharia Mecânica e Materiais, Instituto Federal de Educação, Ciência e Tecnologia do Maranhão (IFMA), São Luís, MA, Brasil.

\footnotetext{
* Contribuição técnica ao 69ำ Congresso Anual da ABM - Internacional e ao 14ํㅡㄹ ENEMET - Encontro Nacional de Estudantes de Engenharia Metalúrgica, de Materiais e de Minas, 21 a 25 de julho de 2014, São Paulo, SP, Brasil.
} 


\section{INTRODUCTION}

The study of the occurrence and interaction of hardening and softening mechanisms during the thermomechanical treatment that interferes directly in the microstructural changes and therefore the variation of the mechanical properties, is very important for the knowledge and process control that will allow an appropriate choice of processing parameters in each stage in industrial scale.

The physical simulation performed through hot torsion testing allows, through the curves of plastic flow and microstructure evaluation of the deformed samples, evaluate the occurrence and behavior of hardening and softening mechanisms depending on the parameters of deformation due to the deformation parameters [1-4].

During the plastic deformation, the metallic materials undergo a hardening process, which contributes to its increased in mechanical strength, referred to as hardening work. The hardening work is characterized by an increase in dislocation density and the type of arrangement that they form [5]. Five types of different restoration mechanisms that operate are identified during, after, or between passes of deformation: the Dynamic Recovery (DRV), Dinamic Recrystallization (DRX), Static Recovery (SRV), Static recrystallization (SRX) and Metadynamic Recrystallization (MDRX) [6, 2-5].

At onset of hot deformation of a metallic material, where the hardening phase occurs, the dislocation density increases with the deformation becoming entangled, but due to the operation of restoration mechanisms, thermally activated, such as cross slip and dislocation climb, occur simultaneity the rearrangement and dislocation annihilation generating regions with relatively low density of dislocation surrounded by high-density of dislocation called cell structure [6-9]. With further deformation, the cell structure can be transformed into subgrains.

In materials with high stacking fault energy, where the partial dislocations is moving closer to each other, thermally activated mechanisms are more effective causing that during the deformation process, the work hardening rate gradually decreases, due to the increase in the rate of dislocation annihilation. When the dynamic equilibrium between these two rates is reached, occur the regime or steady state characterized by a constant flow stress. At this stage the cells are transformed into subgrains, whose perfection, size and disorientation depend on the material, the rate and deformation temperature [8]. Materials with this kind of behavior only presenting dynamic recover.

Metallic materials with middle or low stacking fault energy, the formed cells, have very tangled bounders and are smaller. During the deformation, due to the low efficiency of thermally activated mechanisms since the dislocations movements are more distant from each other, the annihilation rate is less than the rate dislocations generation and when density reaches a critical value the dynamic recrystallization occurs [10]. Dynamic recrystallization is a softening process in which deformed grains are replaced by new ones free of strain. The nucleation and growth of new grains eliminate part of the dislocations generated during the work hardening $[9,11]$. During the phenomenon of work hardening, the density of dislocations increases with strain until a critical energy is reached to initiate the DRX $\left(\sigma_{c}\right.$ and $\left.\varepsilon_{c}\right)$, when the process of nucleation begins $[12,13]$. The rapid annihilation of dislocations with the nucleation and growth of new grains along the grain boundaries existed leads to a peak stress $\left(\sigma_{p}\right.$ and $\left.\varepsilon_{p}\right)$ in the plastic flow curve followed by a rapid softening until the steady state ( $\sigma_{s s}$ and $\varepsilon_{s s}$ ) when the stress is constant with strain. When the stress

* Contribuição técnica ao 69 Congresso Anual da ABM - Internacional e ao 14ํㅡㄹ ENEMET - Encontro Nacional de Estudantes de Engenharia Metalúrgica, de Materiais e de Minas, 21 a 25 de julho de 2014, São Paulo, SP, Brasil. 
reaches the steady state, the recrystallized grains are equiaxed and much smaller than the initial ones.

Another DRX mechanism has also been observed, called necklace mechanism, that preferably occurs at high strain rates and low temperatures. In this, nucleation occurs mainly in the preferred sites of deformation, such as grain boundaries and deformation bands [12, 14-15], preceded by fluctuations in the form of deformed grain boundaries forming new grains [16].

\subsection{Mathematical Modeling of Hot Flow Curves}

The evolution result of the mechanical forces applied by machine over a thermomechanical processing in metallic materials, with the quantity of deformation imposed, is represented by representative graphs curves of stress versus strain $(\sigma \times \varepsilon)$ or plastic flow curves. The stresses levels depend on the mechanisms of hardening and / or softening operative at the deformation time. The fundamentals of mathematical modeling of plastic flow curves of materials that recrystallize dynamically presented below take into account only the parameter of dislocations density, and not considering, therefore, the precipitates formation during the thermomechanical process.

During the plastic deformation, in dynamic recovery regime (DRV), initially there is an increasing in the material resistance, due to the phenomenon of work hardening in consequence of the increase in dislocation density. The evolution of the dislocations density $(\rho)$ with the strain $(\varepsilon)$, in work hardening regime is controlled by the competition between the increase and the annihilation (rearrangement) of these dislocations and can be represented mathematically by two independent terms as shown below in Equation 1.

$$
\frac{d \rho}{d \varepsilon}=\left(\frac{d \rho}{d \varepsilon}\right)^{+}-\left(\frac{d \rho}{d \varepsilon}\right)^{-}
$$

where the first term represents the contribution of work hardening and the second term represents the contribution of dynamic recovery [17-20].

Taking into consideration that the generation of dislocations is independent of deformation [17-20], and the dynamic recovery following a given first-order kinetics [19,21-23], and after some manipulation Equation 1 becomes:

$$
\sigma=\left(\sigma_{\text {sat }}^{2}-\left(\sigma_{\text {sat }}^{2}-\sigma_{0}^{2}\right) \exp (-r \varepsilon)\right)^{\frac{1}{2}}
$$

This equation is the stress versus strain relationship $(\sigma \times \varepsilon)$ for materials that soften intensively by dynamic recovery mechanism in isothermal processing conditions [23]. After the stage of increasing in stress with strain, the stress reaches a certain value of saturation, $\sigma_{\text {sat }}$, in which there is a dynamic equilibrium between generation and annihilation of dislocation, where $d \rho / d \varepsilon=0$.

Differentiating Equation 2, has as a result other Equation and multiplying it for Equation 2 again we have Equation 3:

So, the Equation 2 can be expressed as Equation 3 below:

\footnotetext{
* Contribuição técnica ao $69^{\circ}$ Congresso Anual da ABM - Internacional e ao 14ํㅡㄹ ENEMET - Encontro Nacional de Estudantes de Engenharia Metalúrgica, de Materiais e de Minas, 21 a 25 de julho de 2014, São Paulo, SP, Brasil.
} 


$$
\sigma=\sigma_{s a t}-\left(\sigma_{s a t}-\sigma_{s s}\right)\left[1-\exp \left(-0,693\left(\frac{t}{t_{0,5}}\right)^{n}\right)\right]
$$

The recrystallization kinetics is dependent on the deformation condition imposed to the material. The behavior of the material during the DRX can be represented by the dependence of $t_{0,5}$ with the temperature and deformation rate, ie:

$$
t_{0,5}=A Z^{q} \exp \left(\frac{Q_{D R X}}{R T}\right)
$$

where $q$ and $A$ are constant characteristics of each material associated conditions for deformation, $R$ the universal gas constant, $T$ is the absolute temperature and $Q_{D R x}$ is the activation energy for dynamic recrystallization.

\section{MATERIALS AND METHODS}

The steel used in this work was the austenitic stainless steel ISO 5832-9. The chemical composition of the material by weight is shown in Table 1.

Table 1. Chemical composition of the Austenitic Stainless Steel ISO $5832-9$ (mass \%)

\begin{tabular}{cccccccccccc}
\hline \hline $\mathrm{C}$ & $\mathrm{Si}$ & $\mathrm{Mn}$ & $\mathrm{Ni}$ & $\mathrm{Cr}$ & $\mathrm{Mo}$ & $\mathrm{S}$ & $\mathrm{P}$ & $\mathrm{Cu}$ & $\mathrm{N}$ & $\mathrm{Nb}$ & $\mathrm{Fe}$ \\
\hline 0,017 & 0,16 & 3,62 & 10,6 & 21,06 & 2,44 & 0,0018 & 0,013 & 0,06 & 0,37 & 0,42 & \multirow{2}{*}{ bal. } \\
$(0,08$ máx $)$ & $(0,75$ máx $)$ & $(2-4,25)$ & $(9-11)$ & $(19,5-22)$ & $(2-3)$ & $(0,01$ máx $)$ & $(0,025$ máx $)$ & $(0,25$ máx $)$ & $(0,25-0,5)$ & $(0,25-0,5)$ & \\
\hline
\end{tabular}

Cylindrical specimens with $8 \mathrm{~mm}$ of effective diameter and $12 \mathrm{~mm}$ of effective length were machined out of hot rolled bars. Mechanical tests were carried out on a computerized hot torsion machine. The samples were heated in a furnace by infrared radiation with a maximum power of $6 \mathrm{~kW}$, mounted directly on the testing machine. The measurement and control of temperatures were made by using a Chromelalumel thermocouple fixed in holes drilled near the useful sample part, Figure 1. The instantaneous torque and rotation angle were read and recorded during testing by specific software interfaced to torsion test machine that imposes parametric tests such as temperature, holding time, limit of strain and strain rate.
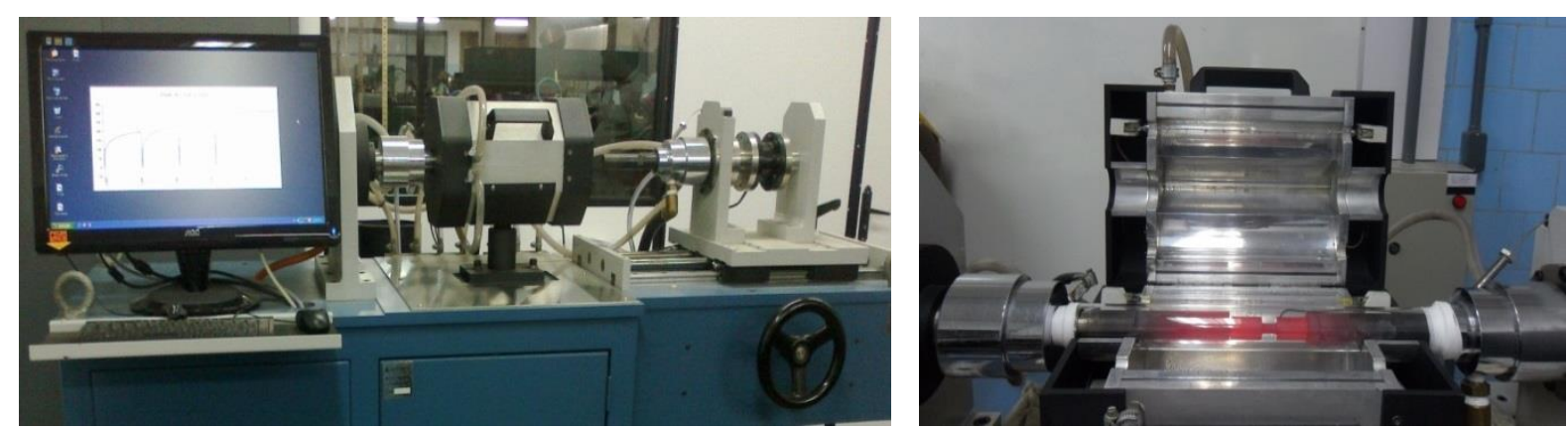

Figure 1. (a) Hot torsion testing machine, (b) Details of infrared furnace with the quartz tube used for heating and rapid cooling of the samples.

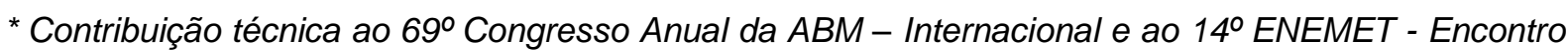
Nacional de Estudantes de Engenharia Metalúrgica, de Materiais e de Minas, 21 a 25 de julho de 2014, São Paulo, SP, Brasil.
} 


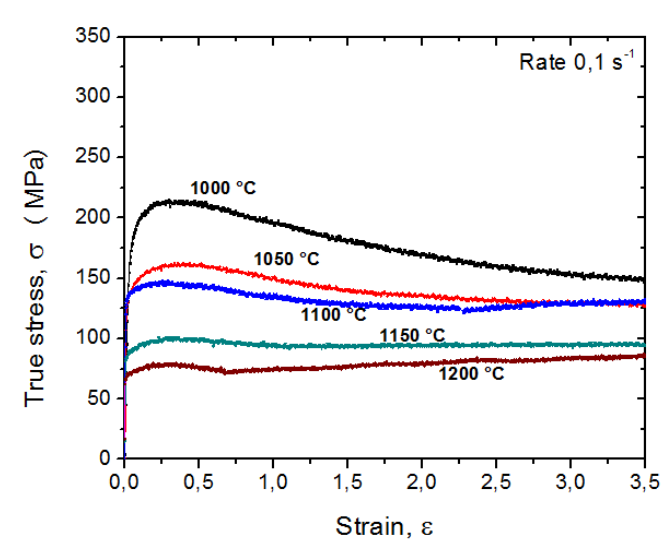

(c)

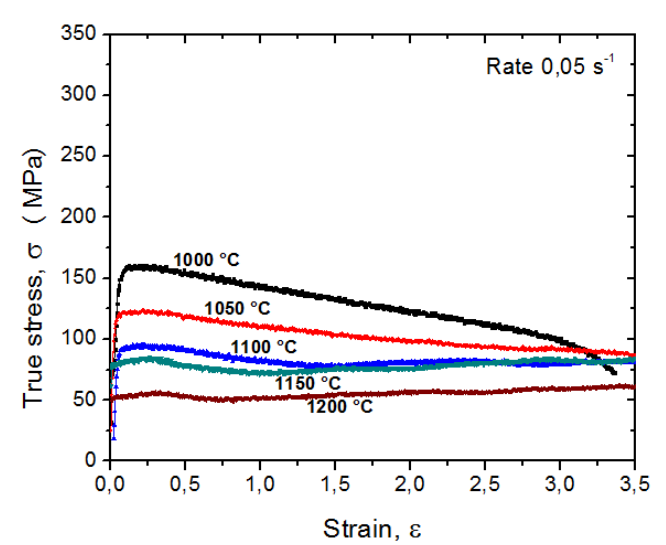

(d)

Figure 2. Plastic flow curves obtained from isothermal continuous torsion tests to different strain rate and temperatures: (a) $5.0 \mathrm{~s}^{-1}$, (b) $1.0 \mathrm{~s}^{-1}$, (c) $0.1 \mathrm{~s}^{-1}$, (d) $0.05 \mathrm{~s}^{-1}$

It is observed in the plastic flow curves shown, that at the beginning there is a region of increasing in plastic flow stress resulting from work hardening mechanism acting, presenting a change in curvature as the material is deformed. With continuing deformation, the stress reaches a maximum value that corresponds to the peak stress. Finally, after a certain strain, the stress reaches a steady state.

The stress level decreases with decreasing strain rate and increasing temperatures. However, the evolution of deformation with thermomechanical treatment condition has distinct behaviors. It is noted that curves at higher temperatures, have the hardening region shifted more to the right and, at lower temperatures the maximum stress tends to occur in smaller deformation.

At the $1000{ }^{\circ} \mathrm{C}$, the samples did not reach the steady state until the imposed deformation during the experimental tests and specifically, at $1000^{\circ} \mathrm{C}$ with $0.05 \mathrm{~s}^{-1}$, the sample failed before the maximum imposed deformation $(\varepsilon=3.5)$, also is worth noting that at this temperature, there is a relatively high drop in tension level in the softening region as the same at high strain rates. In all experiments conducted at higher temperatures, the steady state stress was reached.

\subsection{Constitutive Equation for Peak Stress $\left(\sigma_{p}\right)$}

It is observed clearly in Figure 2 that the stress level in deformation process is dependent on the conditions of thermomechanical treatment, the temperature and strain rate. Having the peak point stress representative of the material behavior, it can be seen that the peak stress $\left(\sigma_{p}\right)$ varies to higher values with decreasing temperature and increasing strain rate, and varies similarly to lower values with increasing temperature and decreasing strain rate. The Garofalo equation, first used for creep and modified by Sellars and Tegart [27] for hot working, represents well the relationship between deformation conditions and the necessary stress for material deformation, represented by followed expression:

$$
Z=\dot{\varepsilon} \exp \left(\frac{Q_{d e f}}{R T}\right)=A\left[\operatorname{senh}\left(\alpha \sigma_{p}\right)\right]^{n}
$$

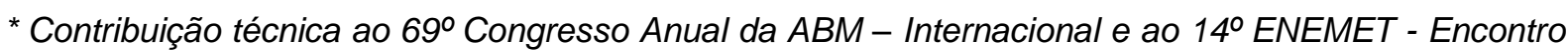
Nacional de Estudantes de Engenharia Metalúrgica, de Materiais e de Minas, 21 a 25 de julho de 2014, São Paulo, SP, Brasil.
} 


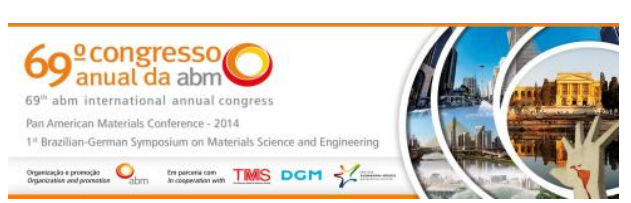

where $\dot{\varepsilon}$ is the strain rate, $Q$ is the apparent activation energy for deformation, $R$ is the gases universal constant, $T$ is the absolute temperature, $Z$ is the Zener-Hollomom parameter, $A, \alpha$ and $n$ are material constants. The constants of this equation were determined applying the method proposed by Uvira and Jonas [28]. A computational procedure was used to determine $\alpha$ value that better fit this equation. This value is attained from substitution the experimental data for strain rate and $\sigma_{p}$ for each one temperature in this equation. With linear regression the $n$ values were determined varying $\alpha$ in the range between 0.002 to 0.052 with step of 0.001 . Plotting the standard deviation of $\mathrm{n}$ as a function of $\alpha$ for each one temperature and strain rate it was possible to see that there is a small range of $\alpha$ values that not depends on the temperature. The $\alpha$ value which presented the smallest standard deviation in all temperatures and strain rate was 0.01313 .

The graph shown in Figure 3(a), shows that the rate of deformation has the same effect on the peak stress in each test temperature, since the lines are substantially parallel. Doing some basic operations in Equation 10, it is arrived to the equation 11, where it is observed that $n$ is the slope of the graph of Figure 3(a). With the values of $\alpha$ and $n$ already found, one can determine the value of the apparent activation energy for hot deformation $\left(Q_{\text {def }}\right)$, Figure $3(\mathrm{~b})$, using the same procedure used to find the value $n$ from Equation 10.

$$
n=\frac{\partial \ln \dot{\varepsilon}}{\partial \ln \left[\operatorname{senh}\left(\alpha \sigma_{p}\right)\right]}
$$

$$
Q_{\text {def }}=\frac{n R \partial \ln \left[\operatorname{senh}\left(\alpha \sigma_{p}\right)\right\rfloor}{\partial(1 / T)}
$$
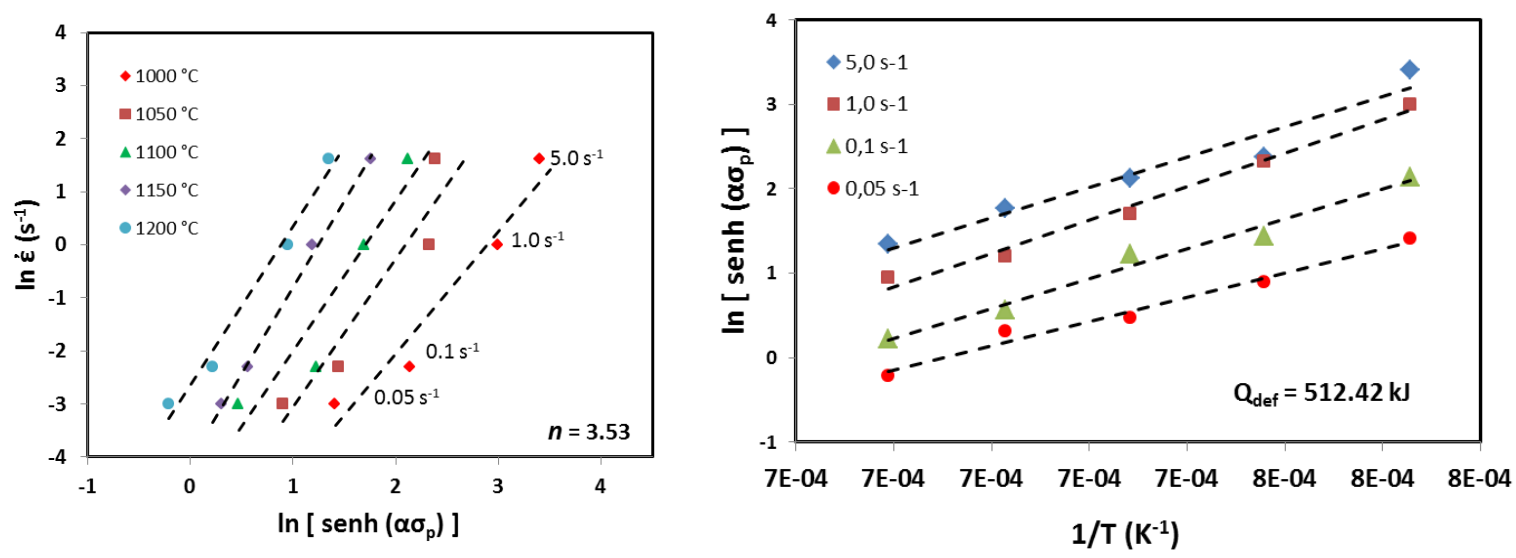

Figure 3. (a) Procedure used to determine the value of $n$ from Equation 15. (b) . Representative plot of the dependence of peak stress $\left(\sigma_{p}\right)$ with the temperature used to determine the apparent activation energy of Equation 16

\subsection{Determination of Softened Fraction and Avrami Exponent}

According to equation 7, the softened fraction at any time in the dynamic recrystallization process $(X s)$, is described as the ratio between the difference of

* Contribuição técnica ao 69 Congresso Anual da ABM - Internacional e ao 14ํㅡㄹ ENEMET - Encontro Nacional de Estudantes de Engenharia Metalúrgica, de Materiais e de Minas, 21 a 25 de julho de 2014, São Paulo, SP, Brasil. 


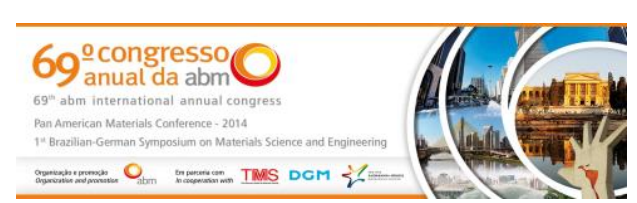

\section{CONCLUSION}

The method used to modeling flow curves for ISO 5832-9 austenitic stainless steel showed a reasonable agreement between modeled and experimental suggesting softening promoted by dynamic recovery and recrystallization after work hardening acting during hot deformation. Standard deviation for the main stress points according to used equation is considered not too high when compered modeling and experimental flow curves. Otherwise, some differences in levels of stresses between modeling and experimental can be speculated from mathematic method that is necessary more investigation to find the cause of these deviations.

\section{Acknowledgements}

The financial support of the Federal Institute of Education, Science and Technology of Maranhão (IFMA) and the Programa de Pós-Graduação em Engenharia de Materiais (PPGEM) is gratefully acknowledged.

\section{REFERENCES}

1 Junior AMJ. Análise do comportamento mecânico de aços inoxidáveis em altas temperaturas e altas taxas de deformação. Tese (Doutorado). São Paulo: Universidade Federal de São Carlos, 1997.

2 Reed-Hill RE. - "Physical Metallurgy Principles", 2ª ed., Litton Educational Pub., ed. D.Van Nostrand Company, 1973.

3 McQueen HJ. Development of dynamic recrystalization theory. Materials Science \& Engineering A, 2003: 203-208.

4 McQueen HJ, Yue S, Ryan ND, Fly E. Hot Working Characteristics of steels In Austenitic State. Journal of Materials Processing Technology, 1995; 53: 293-310.

5 Ryan ND, McQueen HJ. Flow stress, dynamic restoration, strain hardening and ductility in hot working of 316 steel. Journal of Materials Processing Technology, 1990: 21(2): 177-199.

6 McQueen HJ, Jonas JJ. Recovery and recrystallization during high temperature deformation. Treatise on Materials Science and Technology, 1976; 6, London. Academic Press, p. 394.

7 Reed-Hill RE. Physical Metallurgy Principles, $2^{\underline{a}}$ ed., Litton Educational Pub., 1973 ed. D.Van Nostrand Company.

8 McQueen HJ. Development of dynamic recrystalization theory. Materials Science \& Engineering A, 2003: 203-208.

9 Cahn RW. Recovery and Recrystallization. Physical Metallurgy. ed. Wiley, N.Y., 1965 p. 925.

10 McQueen HJ, Jonas JJ. Plastic Deformation of Materials, ed. R. J. Arsebalt, Academic Press e New York,1975, p. 393.

11 McQueen HJ, Ryan ND. Constitutive analyze in hot working. Materials Science and Engineering A, 2002; 322: 43-63.

12 Ponge D, Gottstein G. Necklace formation during recrystallization Mechanisms and Impact on Flow Behavior. Acta Mater, 1998; 46(1): 69-80.

13 Poliak EI, Jonas JJ. Prediction of Interpass Softening from the Strain Hardening Rate Prior to Unloading. ISIJ International, 2004; 44(11): 1874-1881.

14 Wahabi ME, Gavard L, Montheillet FC, Prado JM. Effect of initial grain size on dynamic recrystallization in high purity austenitic stainless steels. Acta Materialia, 2005; 53: 4605-4612.

15 Sakay T, Jonas JJ. Dynamic Recrystallization: Mechanical and Microstructural Consideration. Acta Metallurgica, 1984; 32: 198-209.

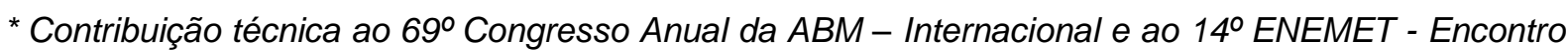
Nacional de Estudantes de Engenharia Metalúrgica, de Materiais e de Minas, 21 a 25 de julho de 2014, São Paulo, SP, Brasil.
} 


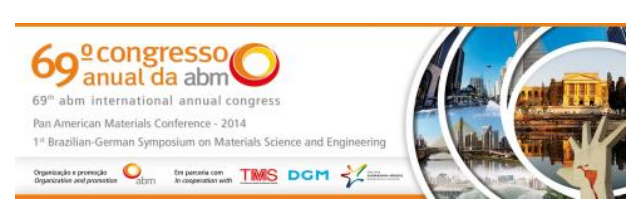

16 Sellars CM. Proc. 7th Int. Symp. on Metallurgy and Materials Science, 1986, Roskilde, Denmark, eds. N. Hansen et al., Riso National Laboratory, 1986, p.167.

17 Laasraoui A, Jonas JJ. Prediction of Steel Flow Stresses at high Temperatures and Strain Rates, Met. Trans., 1991; 22a: 1545-1558.

18 Jonas JJ, Luton MF. Flow Softening at Elevated Temperatures, in Advantages in Deformation Processing, edit by J.J. Burke and V. Weiss, Plenum Pub.Corp., 1978.

19 Estrin Y, Mecking H. A unified phenomenological description of work hardening and creep based on one-parameter models. Acta Metall., 1984; 32: 57.

20 Kocks UF, Mecking $\mathrm{H}$. Physics and phenomenology of strain hardening: the FCC case. Materials Science, 2003; 48: 171-273.

21 Bergstrom Y. The plastic deformation of metals - a dislocation model and its applicability, Reviews on Powder Metallurgy and Physical Ceramics. 1983 p. 79-265.

22 Nabarro FRN. Work Hardening and Dynamical Recovery of FCC Metals in Multiple Glide. Acta Metalurgical, 1989; 37: 1521-1546.

23 Jonas JJ, Quelennec X, Jiang L, Martin E. The Avrami kinetics of dynamic recrystallization. Acta Materialia, 2009; 57: 2748-2756.

24 Poliak El, Jonas JJA One-parameter approach to determining the critical conditions for the initiation of dymanic recrystallization. Acta mater., 1995; 44. 1995(1): 127-136.

25 Poliak El, Jonas JJ. Initiation of dynamic recrystallization in constant strain rate hot deformation. ISIJ International, 2003; 43(5): 684-691.

26 Fields DS, Backofen WA. Determination of Strain Hardening Characteristics by Torsion Testing, Proc. Amer. Soc. Test. Mater., 1957; 57: 1263.

27 Sellars CM, McTergart WJ. Relation between strength and structure in deformation at elevated temperatures. Mem. Sci. Rev. Met.1966; 14: 1136-1138.

28 Uvira JL. Jonas JJ. Hot Compression of Armco Iron and Silicon Steel. Transactions of the metallurgical society of AIME. 1968; 242: 1619-1626.

* Contribuição técnica ao $69^{\circ}$ Congresso Anual da ABM - Internacional e ao 14ํㅡㄹ ENEMET - Encontro Nacional de Estudantes de Engenharia Metalúrgica, de Materiais e de Minas, 21 a 25 de julho de 2014, São Paulo, SP, Brasil. 